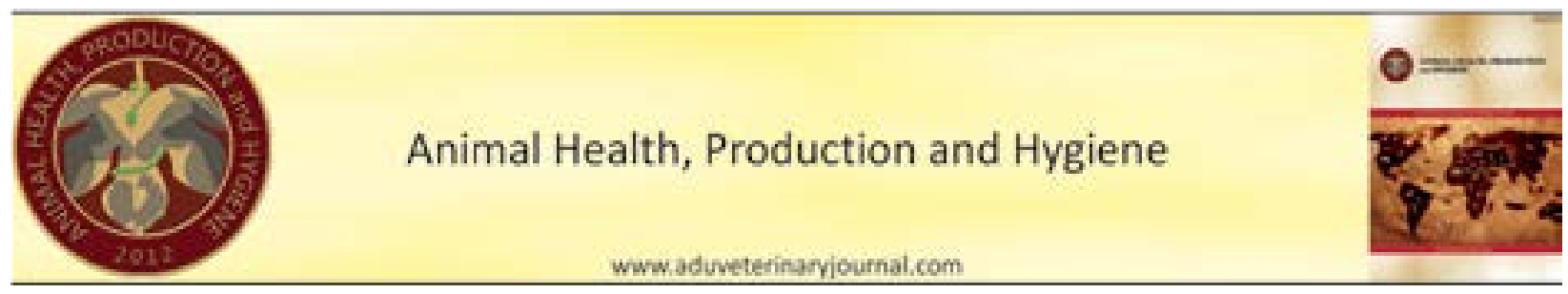

Case Report

\title{
Swimmer Syndrome in Two Kittens
}

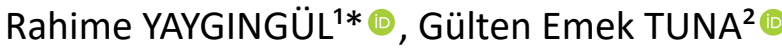

${ }^{1}$ Aydın Adnan Menderes University, Veterinary Faculty, Department of Surgery, 09016, Aydin, Turkey; ${ }^{2}$ Aydın Adnan Menderes University, Veterinary Faculty, Department of Internal Medicine, 09016, Aydin, Turkey.

\begin{abstract}
A B S TR ACT
Swimmer syndrome is a rare developmental abnormality observed in neonatal dogs and cats. This study aimed to give information about the clinical finding and treatment outcomes of swimmer syndrome diagnosed in the two crossbreed kittens. Four weeks old two kittens with the opening of their posterior legs sideways and difficulty walking were brought to the clinic. Clinic examination revealed that the kittens could hold and use both anterior extremities in the normal position; however, both posterior extremities were laterally extended. The kittens had difficulty walking and could not bring their posterior extremities to a normal position. Neurologic and radiologic examinations of the animals were normal. Treatment involved bandaging the lower half of the tibias of the posterior legs with the legs in the normal anatomical posture position. Vitamins $B$ and Vitamin $D_{3}$ were administered to the kittens during treatment as well. This case report describes the successful treatment of swimmer syndrome in two kittens.
\end{abstract}

Keywords: Cat, neonatal disease, swimmer syndrome, treatment

\section{İki Yavru Kedide Yüzme Sendromu}

\section{ÖZET}

Yüzme sendromu, yeni doğan köpek ve kedilerde nadir görülen gelişimsel bir anomalidir. Bu çalışmada iki melez yavru kedide teşhis edilen yüzme sendromunun klinik bulguları ve tedavi sonuçları hakkında bilgi verilmesi amaçlanmıştır. Dört haftalık iki yavru kedi arka bacakların yanlara doğru açılması ve yürüme güçlüğü şikayeti ile cerrahi kliniğine getirildi. Klinik muayenede yavru kedilerin her iki ön ekstremiteyi normal pozisyonda tutabildikleri ve kullanabildikleri; ancak her iki arka ekstremiteleri yanlara doğru açık bir durumda olduğu görüldü. Kedilerin yürümekte zorlandıkları ve arka ekstremitelerini normal pozisyona getiremedikleri saplandı. Hayvanların gerçekleştirilen nörolojik ve radyolojik muayenede herhangi bir anormallik gözlenmedi. Tedavilerinde bacaklar normal anatomik duruş pozisyonuna getirilerek tibianın alt yarımından bandaj uygulaması yapıldı. Tedavi sırasında yavrulara $B$ grubu vitaminler ve $D_{3}$ vitamini uygulandı. Bu olgu sunumunda iki kedide görülen yüzme sendromu başarılı bir şekilde tedavi edilmiştir.

Anahtar kelimeler: Kedi, neonatal hastalık, yüzme sendromu, tedavi 


\section{Introduction}

Swimmer syndrome, also known as swimming puppy syndrome, flat pup syndrome, splay leg (paraparesis), splay weak (tetraparesis), and myofibrillar hypoplasia, is an uncommon developmental musculoskeletal disorder observed in neonatal dogs and cats (Harkness and McCormick, 1982; Hoskins, 2001; Madhu et al., 2015). During the first few weeks of life, affected newborn animals appear normal and gain weight quickly. Clinical symptoms become clear at 2-3 weeks when they try to walk. They cannot lift their bodies off the ground and try to move with their feet open sideways like a swimmer or frog. Affected kittens may have hyperextension at their knee and elbow joints, as well as the lateral opening of the extremities from the hip joints (Hosgood and Hoskins, 1998; Hoskins, 2001; Akgül et al., 2014; Mahesh, 2014). The aetiology of the condition is unclear and may well involve multiple causes. Current theories include hereditary, neurological, environmental, nutritional, obesity-related, maternal metabolic disorders, and musculoskeletal development problems (Hosgood and Hoskins, 1998; Hoskins, 2001; Dumon, 2005; Verhoeven et al., 2006; Bürger et al., 2007; Fossum, 2007; Yardımcı et al., 2009; Linde-Forsberg, 2010).

This disease has been reported in conjunction with deformities such as pectus excavatum thoracic dorsal deviation, dorsoventral compression, patellar dislocation (medial), genu recurvatum, and innocent heart murmur.

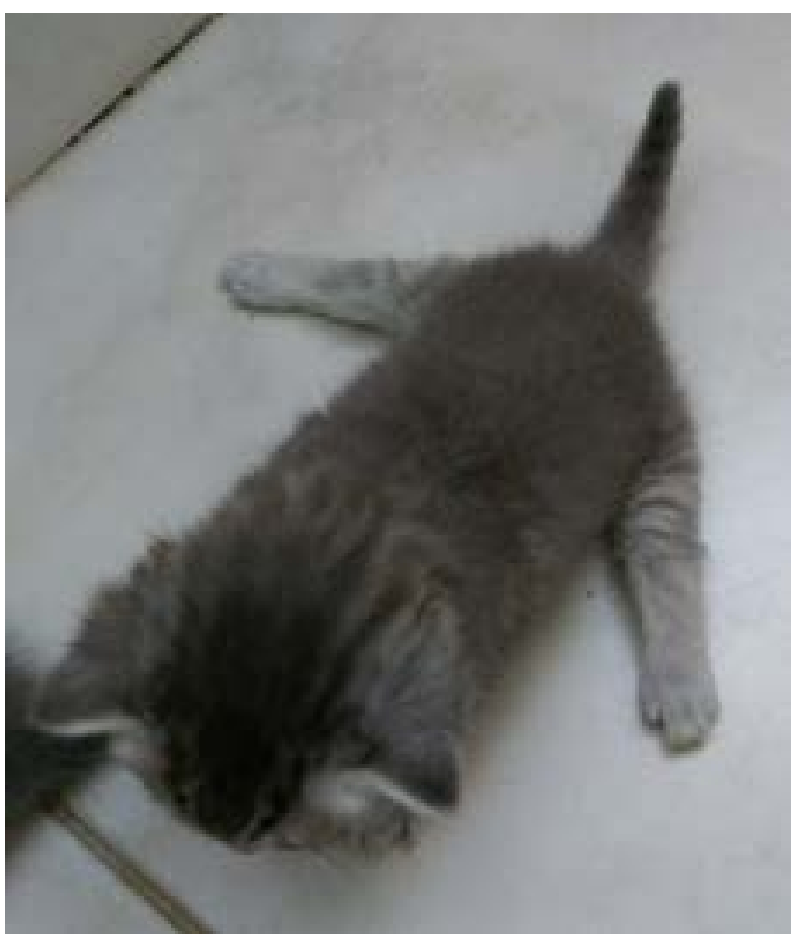

Figure 1. Pre-treatment image of cat with swimmer syndrome.

While a specific treatment protocol has not been documented in the literature (Verhoeven et al., 2006; Yardımcı et al., 2009; Nganvongpanit and Yano, 2013) based upon the suspicious aetiology, many treatment options have been reported, including anatomic immobilization of the affected limbs, using bandages made of eight-girdle or cuffs, physical therapy exercises, thermo- and hydro-therapy, massage for muscle strengthening, vitamin $\mathrm{E}$, and selenium supplementation (Dumon, 2005; Verhoeven et al., 2006; Bürger et al., 2007; Fossum, 2007; Linde-Forsberg, 2010; Cardilli et al., 2013). Literature related to swimmer puppy syndrome in cats is limited. This report aims to describe the syndrome as it affected two kittens and evaluate the treatment results.

\section{Case Description}

Four weeks old two kittens with the opening of their posterior legs sideways and difficulty walking were brought to Adnan Menderes University, Faculty of Veterinary Medicine, Department of Surgery. The owner

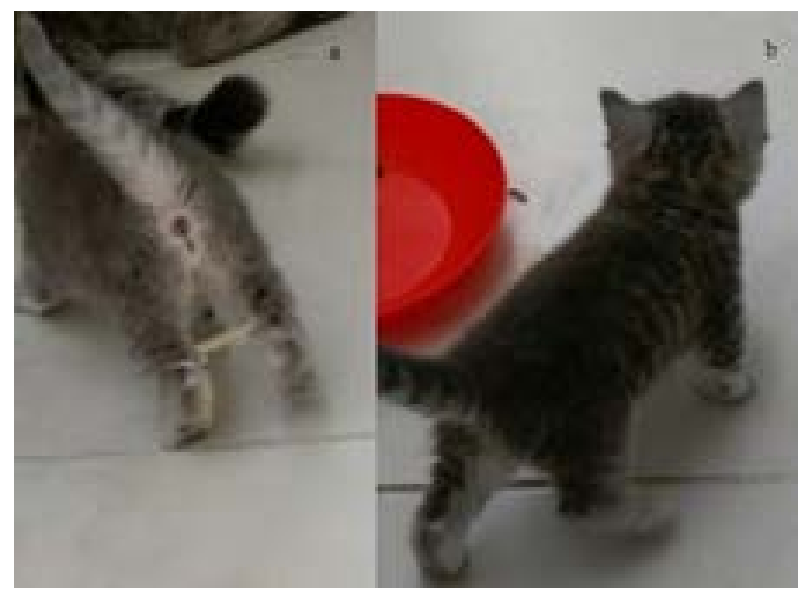

Figure 2. a. Treatment with bandaging applied to the lower half of the tibia of the posterior legs, b. 10th-day post-treatment

of the kittens stated that the queen had six kittens, two of which were affected. One of the kittens was a $350 \mathrm{~g}$ female, and the other was a $400 \mathrm{~g}$ male. The mother was a British Shorthair, and the father was a British Longhair. The owner had observed no abnormalities during the birth of the kittens. Clinical examination revealed that the kittens could hold and use both anterior extremities in the normal position; however, both posterior extremities were laterally open an extension (Figure 1). The kittens had difficulty walking and could not bring their posterior extremities to a normal position. Neurologic examinations were normal. On presentation, all vital signs of both kittens were within normal limits, and they had good body condition. Radiologic examination of the thorax, sternum and pelvis were performed. This radiographs detected normal bone density and bone development. Swimmer syndrome was diagnosed based the animals' history and on clinical findings. Treatment included bandaging applied to the lower half of the tibia of the posterior legs. The leg openings were fixed in the standard anatomical position. The bandage was removed every 12 hours, and physiotherapy was applied to the posterior legs after which the bandaging was re-applied. The bandages were removed after 10 days. There were no bandage-related complications. During 
the treatment, vitamins $B$ (Vitamin $B_{1}: 5 \mathrm{mg} /$ cat/day and vitamin $B_{12}: 50 \mathrm{mcg} / \mathrm{cat} /$ day) and vitamin $D_{3}(0.03-0.06$ $\mu \mathrm{g} / \mathrm{kg} / \mathrm{day}$ ) were administered to the kittens as well. The kittens were able to hold their extremities in the normal position and could walk normally following treatment (Figure 2).

\section{Discussion}

Swimmer syndrome is a rare developmental anomaly in neonatal cats. While developmental abnormalities are present at birth, clinical signs become obvious within the first few days or months. In affected animals, limbs are maintained in an abducted position and attempts to walk resulted in paddling or walrus-swimming movements. In dogs, the problem is more common in brachiocephalic breeds (Harkness and McCormick, 1981; Hosgood and Hoskins, 1998; Yardımcı et al., 2009). In cats, this syndrome has been reported in a Devon Rex and crossbreed kitten (Verhoeven et al., 2006; Gomes et al., 2015). Our cases involved British crossbreeds.

Affected animals look normal in their first weeks. Clinical symptoms emerge at 2-3 weeks when they start to walk. They cannot lift their bodies off the ground and try to move with their feet open sideways like a swimmer (Hosgood and Hoskins, 1998; Hoskins, 2001; Yardımcı et al., 2009; Akgül et al., 2014; Mahesh, 2014). According to Nganvongpanit and Yano, 75\% of posterior extremities, $15.38 \%$ of all four limbs, and $9.62 \%$ of anterior extremities were affected in dogs. Gomes et al., (2015) have reported that only the posterior extremities of cats were affected. In the present situation, clinical findings appeared at two weeks in the posterior extremities of two kittens.

Defects and deformities, such as pectus excavatum, thoracic dorsal deviation, dorsoventral compression, patellar luxation (mediale), genu recurvatum and the innocent heart murmur may arise simultaneously associated with the syndrome (Hosgood and Hoskins, 1998; Hoskins, 2001; Fossum, 2007; Rahal et al., 2008; Linde-Forsberg, 2010; Nelson and Couto, 2015). In this study, defects and deformities were not found in either of our cases.

The causes and pathology of this disease remain uncertain, although several aetiologies and theories have been proposed. Among these, hereditary, environmental (presence of a smooth floor), nutritional (excessive protein in the queen's diet), obesity, maternal metabolic disorders, musculoskeletal development problems, and neurological disorders have been considered (Hosgood and Hoskins, 1998; Hoskins, 2001; Dumon, 2005; Verhoeven et al., 2006; Bürger et al., 2007; Fossum, 2007; Linde-Forsberg, 2010). Based upon to the suspicious aetiology, many treatment options have been proposed including dietary modifications, relocation to a rough surface for motor stimulation, anatomical immobilization of the affected limbs, intensive physiotherapy, thermo/ hydrotherapy and massage for muscle strengthening
(Dumon, 2005; Verhoeven et al., 2006; Bürger, 2007; Fossum, 2007; Lind-Forsberg, 2010; Karcher et al., 2018). According to Hosgood and Hoskins (1998), affected animals have a favourable prognosis if treated early, because bones and articulations are pliable and easy to correct at this stage. In the present case, a bandage passing through the lower half of the tibia was applied. Vitamin supplementation was administered to the kittens as well. According to the literature, the duration of bandaging may vary between 1 week and 1 month, depending upon the animal's response to treatment. In the present cases, after the animals was re-evaluated, the bandage was removed after ten days.

In conclusion, the present report describes the successful management of swimmer syndrome in two kittens.

\section{Conflict of Interest}

The authors declared that there is no conflict of interest.

\section{References}

Akgül, B., Şen, İ.A., Çeşme, H., \& Yanık, K. (2014). Yüzen köpek sendromu. Uludağ Üniversitesi Veteriner Fakültesi Dergisi, 33(1-2), 75-78. https://doi.org/10.30782/uluvfd.384904

Bürger, C.P., Silva, R.B., Canola, J.C., Padilla Filho J.G., \& Oliveira, G.G.S. (2007). Swimmer puppy syndorm: case report. Acta Scientiae Veterinariae, 35 (Suppl 4), 1393-1394.

Cardilli, D.J., João, C.F., Voorwald, F.A., \& Faria, J.L.M. (2013). Swimmer syndrome affecting an entire litter of kittens. Arquivo Brasileiro Medicina Veterinaria e Zootecnia, 65(3), 705-709. https://doi. org/10.1590/S0102-09352013000300014

Dumon, C. (2005). The musculoskeletal system: the first 15 days. Neonatology and pediatrics canine and feline (1st ed.) (pp. 126151). Sao Ca-etano do Sul: Interbook.

Fossum, T.W. (2007). Surgery of the lower respiratory system: Lungs and thoracic wall. In T.W. Fossum, (Ed). Small Animal Surgery (3rd ed.) (pp. 867-895). St. Louis, Missouri: Mosby Elsevier.

Gomes, L.C.V.M., De Santana, V.L., \& De Farias, L.A. (2015). Swimming puppy syndrome in cats. Acta Scientia Veterinariae, 43(1), 109.

Harkness, J.E., \& McCormick, L.F. (1981). Swimming-puppy syndrome in a litter of German Shepherd pups. Veterinary Medicine Small Animal Clinician, 76(6), 817-821.

Hoskins, J.D. (2001). Swimmer puppies and kittens. In: J.D. Hoskins (Ed.): Veterinary Pediatrics (3rd ed.) (pp. 419-420). WB Saunders, Philadelphia.

Hosgood, G., \& Hoskins, J.D. (1998). Musculoskeletal disorders. In G. Hosgood, \& J.D Hoskins (Eds), Small Animal Paediatric Medicine and Surgery (pp. 242-303). Oxford, UK: Butterworth-Heinemann.

Karcher, D.E., Costa, R. C., Prada, T. C., Moraes, P. C. Ramon, L. A., Minto, B. W., \& Dias, L.G.G.G. (2018). A modified technique for treating swimmer puppy syndrome. Veterinarni Medicina, 63(4): 161-167. https://doi.org/10.17221/140/2017-VETMED

Linde-Forsberg, C. (2010). Abnormalities in pregnancy, parturition, and the periparturient period. In: S.J. Ettinger; E.C. Feldman, (Eds). Textbook of Veterinary Internal Medicine (7th.ed.) (pp. 1890-1901). St Louis, Missouri: Elsevier Saunders.

Madhu, D.N., Sivanarayanan, T.B., \& Kumar, R. (2015). Clinical management of swimming syndrome in a Pup. Intas Polivet, 16(1), 136-137.

Mahesh, V. (2014). Swimmer puppy syndrome in a neopolitan mastiff: A case report. Indian Journal Canine Practice, 6(2), 170.

Nelson, R.W., \& Couto, C.G. (2015). Small Animals Internal Medicine (in Portuguese) (5th ed.) (pp. 1512). Elsevier, Rio de Janeiro.

Nganvongpanit, K., \& Yano, T. (2013). Prevalence of swimming puppy syndrome in 2,443 Puppies during the Years 2006-2012 in Thailand. Veterinary Medicine International, 1-6. 
Rahal, S.C., Morishin-Filho, M.M., Hatschbach, E., Machado, V.M.V., \& Aptekmann, K.P. (2008). Pectus excavatum in two littermate dogs. The Canadian Veterinary Journal, 49, 880-884.

Verhoeven, G., De Rooster, H., Risselada, M., Wiemer, P., Scheire, L., \& Van Bree, H. (2006). Swimmer syndrome in a devon rex kitten and an English bulldog puppy. Journal Small Animal Practice, 47(10), 615-619.

Yardımcı, C., Özak A., Nisbet, H.Ö., \& Şirin, Y.S. (2009). Swimming syndrome in two Labrador Puppies. Kafkas Üniversitesi Veteriner Fakültesi Dergisi, 15 (4), 637-640. Doi:10.9775/kvfd.2009.110 


\section{ANIMAL HEALTH, PRODUCTION}

AND HYGIENE

Volume 10, Issue 2 July-December 2021 Page: 39 - 77

Aydın Adnan Menderes University, West Campus, 09016, Efeler, Aydın, Turkey

Tel: + $902562470700 \quad$ Fax: + 902562470720

www.aduveterinaryjournal.org 